\title{
REDISCOVERY OF THE POORLY KNOWN LICHEN-MANTIS Pogonogaster tristani Rehn, 1918 (MANTODEA: THESPIDAE, OLIGONICINAE) IN COSTA RICA AND ECOLOGICAL NOTES
}

Oscar Blanco ${ }^{1}$ Julián A. Salazar-E. ${ }^{2}$

\section{Resumen}

In this paper the rediscovery of the little known Lichen-Mantis Pogonogaster tristani Rehn, 1918 from a new location in Costa Rica, 96 years of being described, is published. Notes concerning the diagnosis of the species, knowledge of the male, the natural habitat and behavior are included.

Palabras clave: behaviour, Costa Rica, Colombia, Oligonicinae, Pogonogaster tristani, Pogonogasterini, new records.

\section{REDESCUBRIMIENTO Y NOTAS ECOLÓGICAS DE LA POCO CONOCIDA MANTIS-LIQUEN Pogonogaster tristani REHN, 1918 EN COSTA RICA (MANTODEA: THESPIDAE, OLIGONICINAE)}

\begin{abstract}
En el presente trabajo se divulga el redescubrimiento de la poco conocida mantisliquen Pogonogaster tristani Rehn, 1918 para una nueva localidad en Costa Rica, después de 96 años en ser descrita. Se incluyen notas relativas a la diagnosis de la especie, el conocimiento del macho, el hábitat natural y comportamiento.
\end{abstract}

Key words: comportamiento, Costa Rica, Colombia, Oligonicinae, Pogonogaster tristani, Pogonogasterini, nuevos registros.

\footnotetext{
*FR: 23-X-2014 . FA: .23-I-2015

${ }^{1}$ Diseñador Gráfico. San Francisco de Heredia, Costa Rica. E-mail: oscarbr@gmail.com; www.micromacrophoto. com

${ }^{2}$ MVZ., Centro de Museos-Historia Natural, Universidad de Caldas. Manizales, Colombia. julian.salazar_e@ ucaldas.edu.co 


\section{INTRODUCTION}

Pogonogaster Rehn, 1918 is a genus of Neotropical Mantids inhabiting almost exclusively the wet cloud forests of the mountains of Central and South America. At present only two species are known: P. tristani Rehn, 1918 of Costa Rica and P. latens Hebard, 1919 of Colombia (BEIER, 1935; TERRA, 1995; EHRMANN, 2002). Pogonogaster tristani is an exceptional and rare species of praying mantis known from a holotype female, and was described by the American James A.G. Rehn. The type locality is the town of La Palma, Costa Rica, and the type specimen was captured by J.F. Tristan in May 1906 and is deposited in the collection of Academy of Natural Sciences of Philadelphia under the catalog number of types 5353 (REHN, 1918; OTTE, 1978) (Figs. 1-3). The species had not been recorded again in Costa Rica up until now and its rediscovery took over 90 years to achieve. Given the importance of this magnificent discovery, we believe it useful to include the original description of both Rehn's genus and species, in addition to providing new data on habitat and behavior of adults plus photographs and a film made by the first author near the type locality.
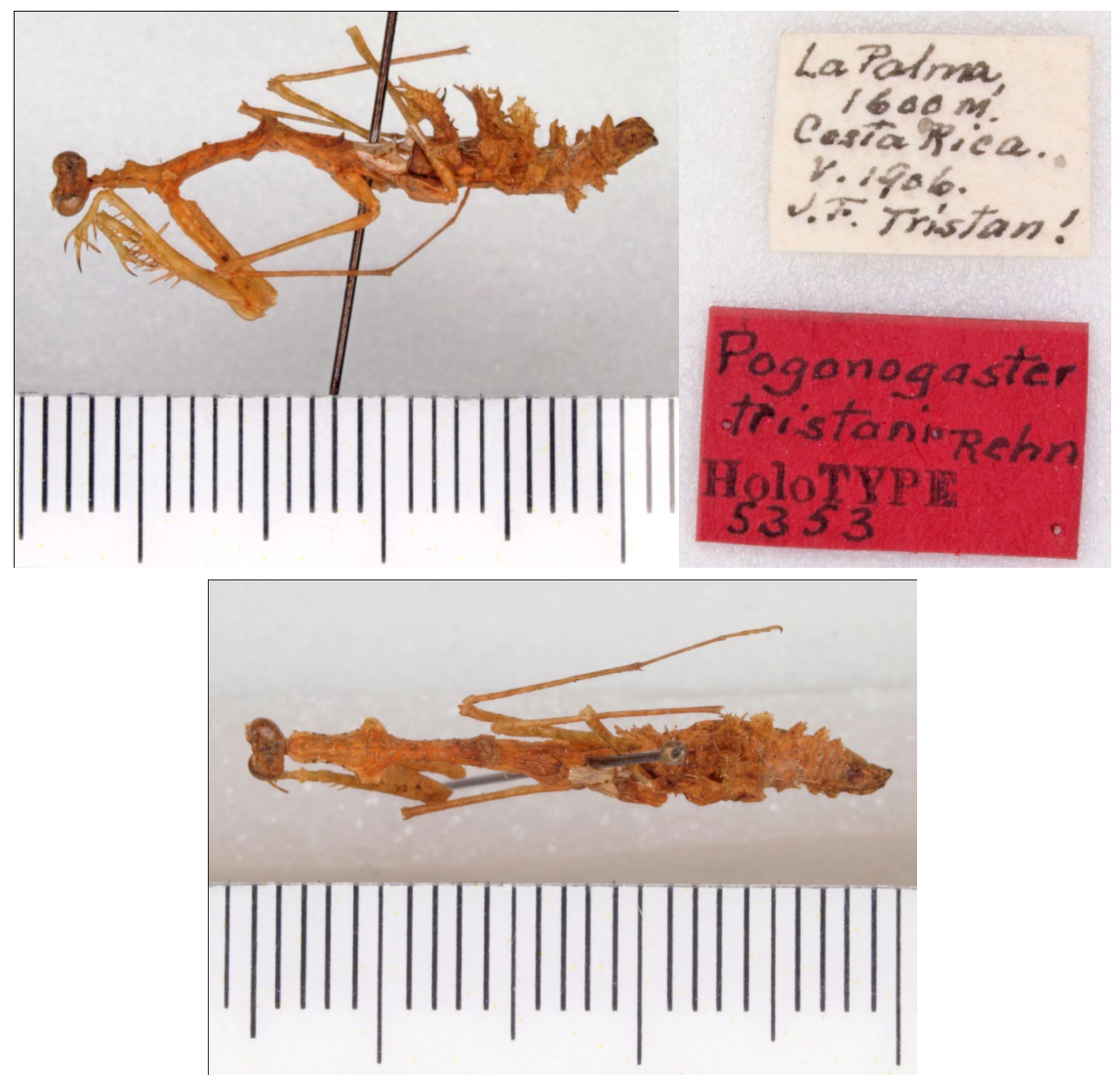

Photos: courtesy of J. Weintraub - ANSP.

Figs 1-3. Lateral and dorsal view of the holotype female of $P$. tristani Rehn and additional labels. 


\section{POGONOGASTER REHN}

\section{Diagnosis of the genus}

(Female) Head transverse; occiput straight, with rounded juxta-ocular elevations; ocelli minute in the female in broad triangle, facial scutellum transverse, eyes rounded. Pronotum elongated, sigmoid in lateral view; supracoxal expansions decided, acute, sub-foliaceus; dorsal surface bearing in the collar a medial and postmedial paired tubercle, or a single low swelling shaft with a pair of tubercles mesad at the caudal margin. Shaft with a distinct median carina, margins serrate. Tegmina and wings in adult (\&) probably undeveloped or abbreviate. Abdomen with the dorsal segments having the caudal margen developed, mesal on the proximal segments into erect foliaceus structures, wich distal are expanded and the margins are serrate-dentate. On the distal segments the structures are merely proyectings folds of the margin, lateral the dorsal segments may or may not developed proximal series of structures similar to the median ones. Venter of the abdomen with a series of medial folds of the caudal margin of the segments. Supranal plate (ㅇ) tectate, carinate dorsad. Cephalic femora with distal five-eigths very slender discoidal spines three in number, cephalic tibiae abbreviate no at third as long as the femora, in addition to the claw with an internal and external two distal spines. Proximal portion of the ventral margin with a series of several small denticulations, median and caudal limbs elongate; femora faintly swollen in the pregenicular region, genicular lobes produced round and acuminate caudal metatarsi forming distinctly more the half of the entire tarsal length. Genotype: P. tristani Rehn.

\section{COMMENTS}

According to the preliminary review by Rehn, Pogonogaster is a member of Miopterygides and belongs to the subfamily Oligonicinae without much relation to other known genera. However it apparently approaches the genera Harpagonyx and Spanionyx Saussure, 1892, (currently synonyms of Oligonyx Saussure, 1869) and Thrinaconyx Saussure, 1892, but differs by its truncated occiput and lacks angular juxta-ocular lobes. The shape of the pronotum is of subsigmoide aspect laterally, reminiscent of the mantids of Toxodera Serville, 1837, an Old World genus, and by the tuberculate dorsum of pronotum and abdominal foliaceous extensions and other characters described above by this author. Rehn pointed out the close affinity of the genus with the Oligonicine Miopterygides that its evident by more detailed studies and recently confirmed by WIELAND (2013) after analyzing certain clades or groups including Thrinaconyx and members of Haaniinae subfamily.

\section{REHN (1935) comments:}

[...] this most unusual mantid, with the related genus Carrikerella Hebard, 1921 occupies an anomalous position in the Oligonicine, due to the foliaceus lobing of the abdomen of the female and the structure of the elongate pronotum. Its whole form, as well as coloration, is of protective character and admirably serves in this respect.

Pogonogaster has also been redescribed or quoted by other authors in particular GIGLIO-TOS (1927), BEIER (1935), TERRA (1995), JANTSCH (1999), EHRMANN (2002) and EHRMANN \& KOCAK (2009). BEIER (1935) establishing the genus as 
the type of Pogonogasterini tribe (= subtribe Pogonogasterees) because of the unusual morphological features shared with other related genera within the subfamily Oligonicinae including the genera Carrikerella Hebard, 1822; Liguanea Rehn \& Hebard, 1938; Mantellias Westwood, 1885; Mantillica Westwood, 1889; Pseudopogonogaster Beier, 1942 and Thesprotia Stal, 1877 (BEIER, 1935, 1964; AGUDELO et al., 2007; EHRMANN \& KOCAK, 2009).

\section{Pogonogaster tristani Rehn}

\section{Original description}

Size medium, form moderately elongate, abdomen fusiform, surface unpolished. Head in general form transverse, subtrigonal: occiput in cephalic aspect transverse truncate, with very low and rounded juxta-ocular swellings: front dorsad of the ocelli with arcuate carination: facial shield strongly transverse, low the width at least three times the greatest depth, dorsal margin arcuate, clypeus produced in a conical tubercle: eyes prominent, almost semicircular in outline when seen from the front, and subglobose in dorsal view, in lateral view the eyes are ovate in basal outline: antennae imperfect, proximal joint small. Pronotum when seen from the dorsum with form elongate cruciform. The greatest width across the supra-coxal expansion subequal to the length of the collar and about two-fifths of the entire pronotal length, from the side aspect the pronotum is bisigmoid: collar with the margin well rounded cephalad, faintly narrowing at the middle of the collar, thence regular expanding to the acute apices of the supra-coxal expansions, the latter subfoliaceus and arcuate dorsad shaft regularly narrowing from the maximum width of the supra-coxal expansions to about the cephalic two-fifths of the shaft. Surface of the pronotum with on the shaft a decided median conical tubercle and a smaller but similar one cephalad of the media protuberance, on the shaft at the caudal margins situated a pair of prominent tubercles, collar with faint medial carina.

Tegmina and wings represented by well-veined lateral pads: mesonotum and metanotum with a distinct medial carination. Abdomen with median line of the second, third and fourth segments of the abdomen developed, erect foliaceus appendages, wich each consist of a single thickness cephalad and lateral wings to the same caudad, the wings more ample that the single portions and broaden distad than proximad, the margins of the appendages with numerous digitiform points, the appendage on the fourth segment smaller than the other two, fifth to ninth segments with median line bearing low appendages, wich are more nearly erect fold of the integument than true lobes, lateral appendages developed on the second to fourth segments very similar in character to those on the median line, ventral abdominal segments with a median fold at the caudal margin: supra-anal plate elongate linguiform, decurved, subtectate, carinate mesad: cerci simple, no tapering, no reaching to the apex of the supra-anal plate: subgenital plate short, of the usual rostrate mantid type.

Cephalic coxae three-fourth as long as the pronotum, slightly inflated proximad, more slender distad, internal face with distal lobe moderately developed, margin sparsely, denticulate: cephalic femora slender, faintly sigmoid, distal five-eigths tapering, very slender, median discoidal spine the longest of the three; external margin with five spines of wich the distal one is much the shortest; internal margin with nine spines arranged in the formula: iIIIIIIi; margins of the cephalic femora 
other than those sections bearing the regular spine series sparsely dentate, the medio-ventral one distinctly and regular serrate-dentate. Cephalic tibiae (without claw) no quite one-third as long as the femur, subsigmoide, apical claw large, slender moderately falcate; dorso-distal section with a prominent falcate spine and a smaller straight spine immediately ventral of the largerspine and on the internal face; internal margin with a single median large oblique spine; external margin with a single straight spine distal; ventral margin proximal with 3 minute serrations. Cephalic tarsi incomplete. Femora subcompressed and faintly arcuate, immediately before the distal extremity; genicular lobes subacuminate, caudal tarsi very faintly shorter than the tibiae, very slender, the metatarsus comprising five-eighths of the tarsal length.

General color antimony yellow, becoming dull buckthorn brown on the abdomen, the shaft of the pronotum washed with ferruginous; limbs of the body color passing into weak and pale turtle green, the spines fuscous tipped; head with the occiput washed with dull mummy brown, eyes dresden brown. Length of body, 25.5 m.m.; length of the pronotum, 8.3; length of cephalic femur, 7.5; length of caudal femur, 8.3.

Also, JANTSCH (1999) and EHRMANN (2002) cited a male (Figs. 4-5) deposited in the Department of Entomology at the University of Minnesota (now known as the Bell Museum) which according to the labels is from the Guanacaste province, Costa Rica (Tenorio-San Lorenzo, Tierras Morenas, $900 \mathrm{~m}$.) and was captured in February 1992. Ehrmann assigned this specimen as the male holotype of P. tristani, however Dr. Robin Thomson, curator of the collection, could not find a holotype designation, only an additional handwritten label from October 1994 by Lauro J. Jantsch determining the species as such.

\section{ECOLOGICAL NOTES}

In addition to the original description of P. tristani by REHN (1918), in 1935 the same author related more detail aboutthe habitat type locality after two visits the scientist conducted in 1923 and 1927 in order to locate more specimens of this species, but without positive results. However a student (Prof. J.F. Tristan) collected another specimen some years earlier but with an unknown exact location. According to this author, La Palma is $1600 \mathrm{~m}$. above sea level (5000 feet) on the pass between the western side of Irazú volcano and the Zurquí near to Barba volcano. This pass was traversed by an old road from the abandoned terminal "Linea Vieja" and Carrillo to the capital city, San José. The locality consisted of a small group of goat and cattle ranches with meadows and pastures interspersed by patches of subtropical cloudrainforest which prevails in mountainous areas of the entire passin mention. Most of the year the northeast trade windsbring moisture vaporthrough the La Palma pass. Days of sunshine duringthe wet season are exceptional, normally there is a permanent fog blanket with frequent rain or drizzle. Consequently the trees of the forest are buried in epiphytic vegetation: bromeliads, creepers, ferns and mosses covering the bark and even the fence posts and telephone wires. 

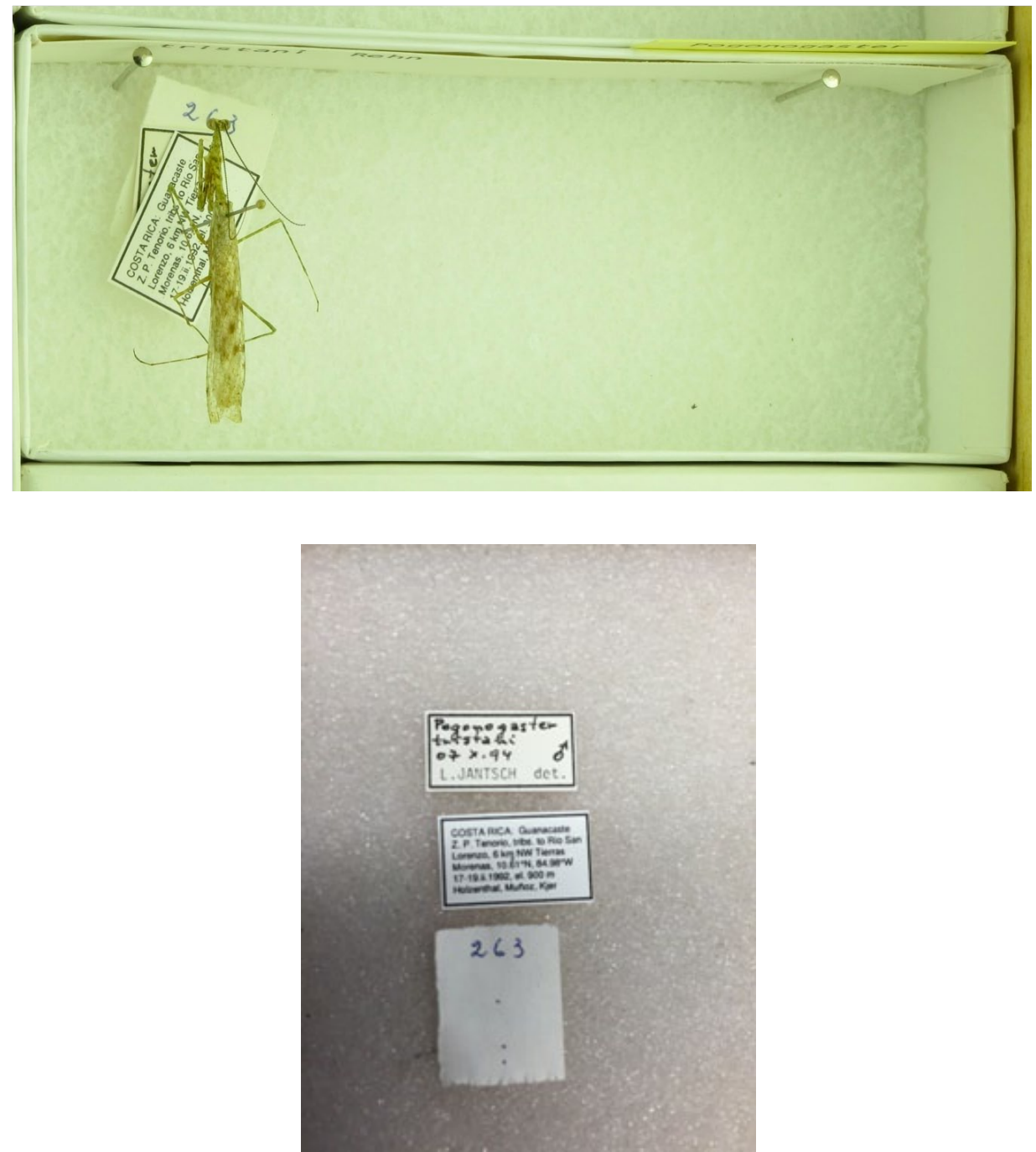

Photos: courtesy of Robin Thomson - Bell Museum.

Figs 4-5. Dorsal view of the holotype male of P. tristani Rehn and additional labels.

Recently however, on July 14, 2012, in the province of Heredia, San Rafael, at a location known as the "Bosque de la Hoja", the first author was fortunate in recording in situ two specimens of Pogonogaster ascribed to P. tristani. On this date an adult female was observed, and on October 5, 2013 a nymph of the same sex (Figs. 6-11). Unlike the description of REHN (1935) on the specific habitat of $P$. tristani, citing its habitat as the mantle of epiphytes that exist on the trunks of the trees of the native forest, the new location of Bosque de la Hoja, is composed of a patch of planted pines (Pinus patula) and cypress (Cupressus, Podocarpus) (FOURNIER et al., 1966) located at $1732 \mathrm{~m}$ above sea level. These trees are arranged 
as a cordon and surrounded by green areas and roads but even though planted, moss covers the trunks of these trees and this is precisely the habitat where the new specimens of Pogonogaster were observed (Fig. 12).

The unusual shape of the body of Pogonogaster with a multilobed abdomen, the thin gnarled sides of the pronotum, and its greenish yellow color help it blend in with mosses and the epiphytes growing on the trees, as occurs with other genera of related mantids such as Pseudopogonogaster Beier, 1942; Carrikerella Hebard, 1921 and certain phasmids belonging to the genera Mirophasma (Redtenbacher, 1906), Acanthoclonia (Stal, 1875) and Laciniobethra Conle, Henneman \& Gutierrez, 2014 (AYALA \& ONORE, 2001; SALAZAR \& CARREJO, 2002; SALAZAR, 2006; GUTIÉRREZ \& BACCA, 2014; GUTIÉRREZ-VALENCIA et al., 2014).
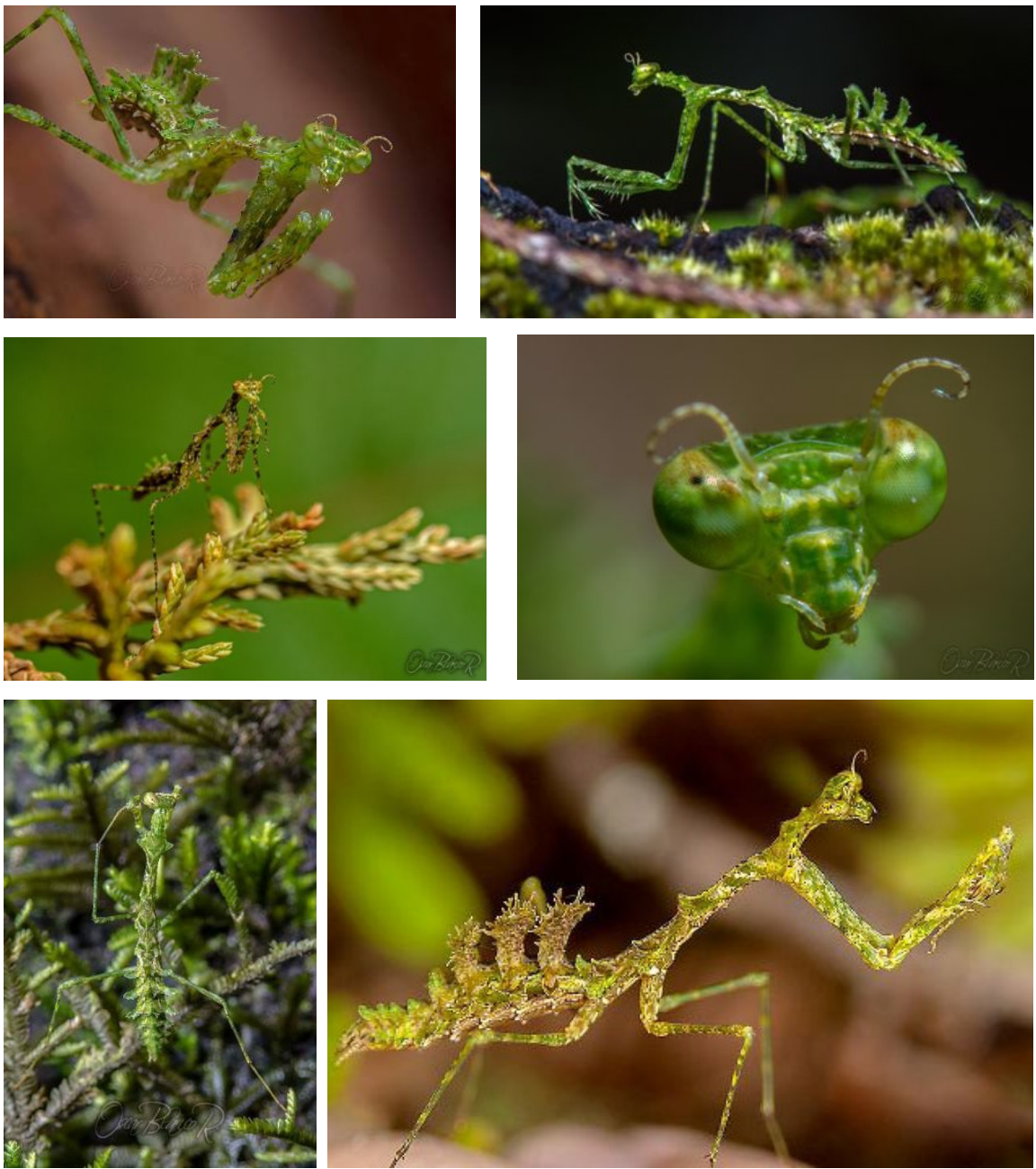

Photos: O. Blanco.

Figs 6-11. Pogonogaster tristani adult female and nymph in situ Bosque de la Hoja, Heredia, Costa Rica. 


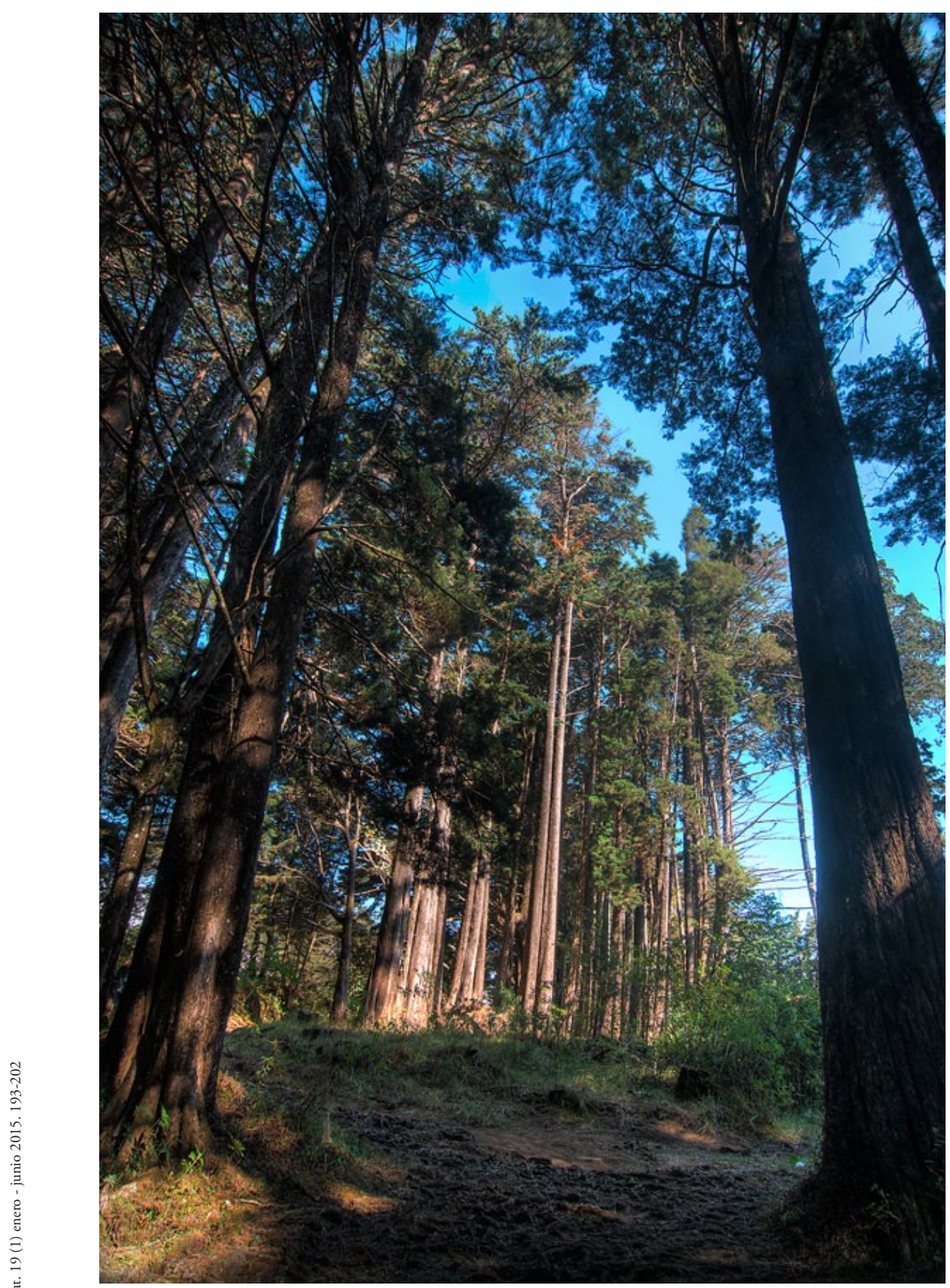

Photo: O. Blanco.

Fig 12. Bosque de la Hoja Park showing the cypresses and pines, the newly discovered habitat of P. tristani. Heredia, Costa Rica. 


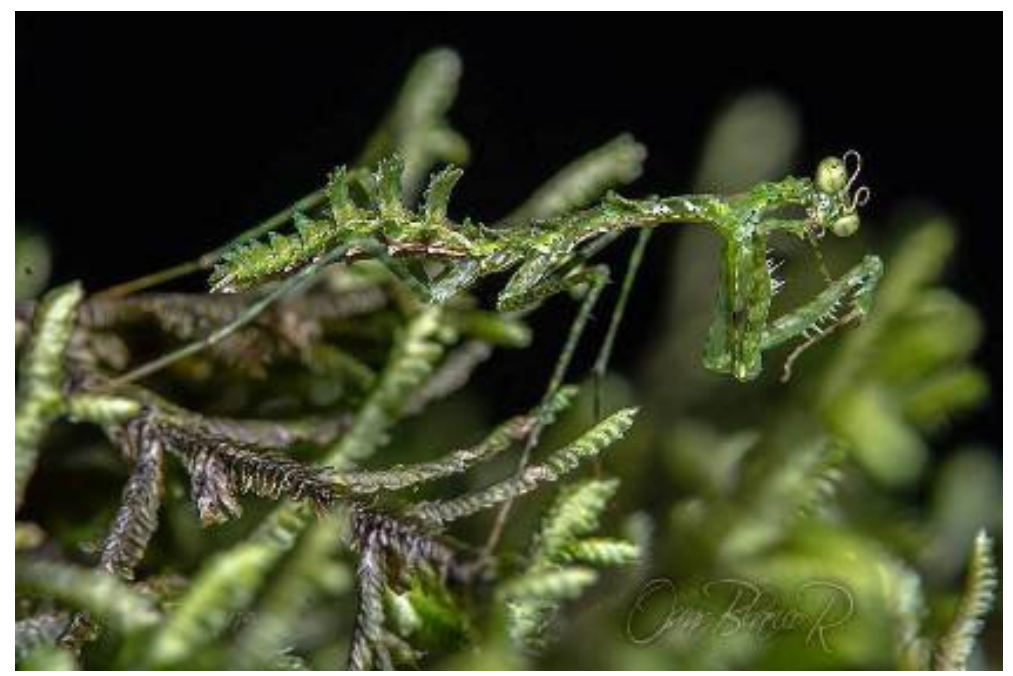

Photo: O. Blanco.

Fig 13. A female Pogonogaster tristani nymph preening.

It should be noted that the second known species of Pogonogaster. P. latens Hebard, 1919 of Colombia, is found in similar mountainous regions (REHN, 1935) and has not been recorded since its description (SALAZAR \& RÍOS-MALAVER, 2012). The authors will continue in this urgent mission to rediscover two of the most enigmatic mantids of the Neotropical region ever described.

\section{ACKNOWLEDGEMENTS}

Special thanks to Dr. Jason Weintraub collection manager of the Department of Entomology, Academy of Natural Sciences of Philadelphia - ANSP (USA) for sending the picture of the type of P. tristani under his care. Also thanks to Dr. Susan Weller, director and professor of the J. Bell Museum of Natural History and Robin E. Thomson, insect collection curator of the department of Entomology, University of Minnesota (USA) for providing photographs of the male. Literature concerning the subject was graciously sent by Mauricio Bollino (Italy), Paul S. Terra (Brasil), Reinhard Gaedike (Deutschen Entomologische Institute - DEI), Reinhard Ehrmann (Naturkunde Museum, Karlsruhe, Germany) and Frank Wieland (Zoologisches Museum of Hamburg). To Greg Nielsen for the English text corrections.

\section{BIBLIOGRAPHY}

AYALA, M. \& ONORE, G., 2001.- Los mántidos (Ins. Mantodea) del bosque nublado Otonga y áreas aledañas (en) NIEDER \& BARTHLOTT (eds.) Epiphytes and canopy fauna of the Otonga rain forest. Bot. Inst. Bohn., 2: 243-260 + figs.

AGUDELO, A., LOMBARDO, F. \& JANTSCH, L., 2007.- Checklist of Neotropical Mantids (Ins. Dyct. Mantodea). Biota Colombiana, 8 (2): 105-158. 
BEIER, M., 1935.- Mantodea, subf. Thespinae (in) WYTSMAN, P. (ed.. Genera Insectorum, 200: 32 pp. + 2 pls. L.D. Vert., Tervuren.

, 1964.- Ordnung Mantodea Burmeister, 1838. Brons classen das Tierreichs, 5 (3): 850-969 + figs.

EHRMANN, R., 2002.- Gattung Pogonogaster Rehn, 1918: 284-285. Gottensabeterinen der Welt, Natur und Tier, Verlag.

EHRMANN, R. \& KOCAK, A., 2009.- The Neotropical Mantids (Ins. Dyct. Mantodea). Cesa News, 49: 15-16.

FOURNIER, L., SALAS, S., JIMÉNEZ, A. \& MARÍN, F., 1966.- Las familias y géneros de árboles y arbustos de Costa Rica. Rev. Biol. Trop., 14 (2): 317-328.

GIGLIO-TOS, E., 1927.- Orthoptera, Mantidae. Das Tierreich, 50: 274. Berlín und Leipzig.

GUTIERREZ, Y. \& BACCA, T., 2014.- Phasmatodea (Ins.) de la Reserva Natural Río Nambi, Nariño, Colombia. Bol. Cient. Mus. Hist. Nat. U. de Caldas, 18 (1): 210-221 + figs.

GUTIÉRREZ-VALENCIA, J., GUTIÉRREZ, Y. \& HURTADO, F., 2014.- Eres como lo que comes? Relación entre el uso de microhábitat para el ocultamiento críptico y dieta en Laciniobethra spp. (Phasm. Diaph.). Bol. SEA., 55: 265-272 + figs.

JANTSCH, L.J., 1999.- Estudos filogenéticos en Mantideos Americanos (Ins. Mantodea): Tesis doctoral. $137 \mathrm{pp}+$ figs. PUCRS.

OTTE, D., 1978.- The Primary types of Orthoptera (Saltatoria, Mantodea, Phasmatodea and Blattodea) at the Academy of Natural Sciences of Philadelphia, Mantodea. Proc. Ac. Nat. Sci. Philadelphia, 130: 75-77.

REHN, J.A.G., 1918.- Descriptions of one new genus and fifteen new species of tropical American Orthoptera. Trans. Amer. Ent. Soc., 54: 326-328.

, 1935.- The Orthoptera of Costa Rica, part I Mantidae. Proc. Ac. Nat. Sci. Philadelphia, 87: 194195 + figs.

SALAZAR, J.A., 2006.- Variaciones cromáticas en ejemplares de Stagmomantis tolteca Saussure, 1871 en Caldas y Pseudopogonogaster iguaquensis Salazar \& Carrejo, 2002 en la Reserva Natural Rogitama, Boyacá (Ins. Mantodea). Bol. Cient. Mus. Hist. Nat. U. de Caldas, 10: 312-322 + figs.

SALAZAR, J.A. \& CARREJO, N., 2002.- Nueva especie de Pseudopogonogaster Beier, 1942 para la Cordillera Oriental de Colombia (Ins. Mantodea). Bol. Cient. Mus. Hist. Nat. U. de Caldas, 6: 103-109 + figs.

SALAZAR, J.A. \& RÍOS-MALAVER, C., 2012.- Apuntes taxonómicos sobre mántidos neotropicales e ilustración de algunos tipos descritos de Colombia (Ins. Mantodea). Rev. Investigación UNISAR., 10 (1): 16-23 + figs.

TERRA, P. S., 1995.- Revisão sistemática dos gêneros de Louva-Deus da Região Neotropical (Mantodea). Rev. Bras. Ent., 39 (1): 13-94 + figs.

WIELAND, F., 2103.- The Phylogenetic System of Mantodea (ins. Dyct.). Spec. Phyl. Evol., 3 (1): 222 + figs. 